\title{
Determinants of Loan Default of Low-Income Borrowers in Urban Informal Credit Markets: Evidence from Dhaka City
}

\author{
Md. Main Uddin, PhD \\ Professor, Department of Banking and Insurance \\ University of Dhaka, Dhaka-1000, Bangladesh
}

\begin{abstract}
A major problem for credit markets is to discover the factors that are responsible for the non-repayment of loans. This study identifies the factors which are liable to loan default in urban informal credit markets. A questionnaire survey was conducted among four hundred low-income people in Dhaka city who took loans from informal credit markets. A logistic regression was used to find out the factors which cause loan default in these markets. The results show that loan default is strongly related to interest rate, size of loan, loan diversion, and collateral of loan. In addition, multiple sources of income, borrower's monthly income, education and age play important roles in this regard. The identification of the factors affecting loan default is expected to help the loan providers of both informal and formal credit markets to reduce default loans and establish discipline in financial markets.
\end{abstract}

Keywords: Determinants; Loan default; Low-income borrower; Informal credit market; Dhaka

DOI: $10.7176 / \mathrm{EJBM} / 11-26-10$

Publication date:September $30^{\text {th }} 2019$

\section{Introduction}

Informal credit markets are the markets where lending and borrowing activities occur among friends, relatives, kin members, landlords, neighbors, shopkeepers, farmers, moneylenders and other local income groups. They provide non-institutional loan facilities organized outside a country's legal system. They are an important part of the financial system of a developing country like Bangladesh because formal credit markets suffer from some problems which deter a section of people especially the poor from taking loans from them. Collateral risk (Boucher and Guirkinger, 2007), tedious paper work, bureaucratic loan process associated with formal loans (Foltz, 2004), asymmetric information and also the political reasons (Zander, 1994) and the availability of formal credit institutions $(\mathrm{He}, 2007)$ are the main obstacles to the demand for formal credit markets.

On the other hand, informal credit has some unique advantages for which people still depend largely on it. Roe (1979) and Timberg and Aiyar (1980) state that informal credit markets provide valuable services that are not adequately met by modern financial corporations. The lenders in informal markets do not need collateral for loans. They can do so mainly because they have better information about borrowers from being insiders and they can use other mechanisms (Bell, 1988; and Bardhan and Udry, 1999) to ensure that borrowers do not default. The informal credit markets will continue to prevail because of their flexible loan production technology, low transaction cost and unmet demand for credit (Hoque and Khalily, 2002). Unlike commercial banks, informal lenders use personal, social and business relationships to pre-select clients (Qadir, 2005). Moreover, informal credit is often a matter of verbal agreement without contract (Tand, Guan and Jin, 2010). Informal credit markets know their customers well and closely monitor their business, payment records, overall prosperity, integrity and cash position of their customers (Nisber, 1967 and Holst, 1985). Informal lenders have detailed knowledge of the borrowers and they therefore can separate out high-risk and low-risk borrowers and charge them appropriate interest rates; and they can monitor the borrowers more effectively, making sure that the funds are used productively and thus lowering the default rate (Stiglitz, 1990).

Because of proximity between lenders and borrowers, the former have more information about the latter which helps in making effective lending decision. The lender can also closely monitor the borrower's activities even after sanctioning a loan and thus the loan repayment rate is expected to be high in such markets. However, such advantages of informal credit markets do not completely reduce the probability of loan default because for any relationship where payment is made now and repayment is made over time, the possibility of default is always present (Qadir, 2005). Thus, informal credit markets are ended up with some loan default that may result from several factors.

An informal credit market that extends loans to the borrowers who have no or limited access to formal markets is a boon and should be encouraged to remove the liquidity constraint of the poor as long as the formal sector fails to reach them. What is important in this regard is to increase the capacity of the lenders of such markets so that they can continue to serve the borrowers. In order for that informal lenders must ensure the high repayment of loans to increase the recyclability of funds. In order to ensure recyclability and high recovery rate, it is needed to identify the factors that cause loan default in the informal credit markets. The tale of formal credit markets where loans are mainly provided by banks and non-bank financial institutions to borrowers who use them generally in the formal sectors of an economy is well heard, but what about the informal credit markets on which the low 
income people depend for their financial needs? Or the loan default status and the factors that cause the loan default in such markets? Such questions have received surprisingly little attention in credit market research. This study considers the urban informal credit markets worth investigating and tries to present the factors that determine loan default in such markets.

Informal credit markets play a significant role in channeling funds mainly to poor borrowers both in rural and urban areas. A section of people depend largely on informal credit markets. Informal finance will prevail in an economy because certain groups are excluded from formal credit institutions and these groups will continue to turn to private lenders (Lainez, 2014). However, there exists a few literature (e.g. Hoque and Khalily, 2002) on informal credit markets, given the fact that formal lending institutions with their lending technology characterized by high transaction cost and presence of collateral fail to reach the low income people. Less effort has been engaged to know about informal credit markets especially in urban areas of Bangladesh although they play a significant role where the formal lending institutions cannot serve the poor. More specifically, the loan default status and the determinants of loan default rate in the case of informal credit markets in urban areas are not clearly understood.

The poor in urban areas depend largely on informal loans. All borrowers cannot repay the loans on time although informal lenders consider many factors before sanctioning loans. Such default is caused by many factors. Hence, it is essential to know the factors that are responsible to loan default. However, academic research on this issue is almost absent. Literature thus indicates that an essential question, still unresolved empirically, is what factors cause default in urban informal credit markets and what particular influence they have towards loan default. Until we know the factors inducing loan default, a major aspect of urban informal credit markets will remain unexplored. Therefore, this paper attempts to shed light on the issue of loan default in informal credit markets by providing empirical evidence from Dhaka city of Bangladesh. It appears that loan default is caused by interest rate, loan diversion, collateral, multiple income sources, borrower's age, education, size of loan and level of income.

This paper makes some contributions to loan default literature. This is the first paper that examines the relationship between loan default and its determinants by taking urban informal credit markets into consideration. There is shortage of literature which focuses on the empirical relationship between loan default and the variables that cause the default especially in the urban informal credit markets. Considering the urban informal credit markets worth investigating, this paper provides definitive empirical evidences of the factors that cause loan default. This area of study largely remains unexplored by previous researchers who mainly contributed much towards to formal credit markets. It mainly identifies the factors that cause loan default in urban informal credit markets. The rest of the paper is organized as follows. Section 2 outlines the literature review and development of hypotheses. Section 3 gives a description of the data, the variables and the model used in the paper. Section 4 presents the empirical results and discussion. Section 5 makes concluding remarks.

\section{Literature Review and Hypothesis Development}

A default loan may be defined as a loan which is not paid according to its promised terms and conditions. A loan may be defaulted partially or fully. Default is the likelihood that a borrower misses payment or does not meet the conditions of an agreement or indenture (Sobehart, Keenan and Stein, 2001). Loan default can be defined as the inability of a borrower to fulfill their loan obligation when due (Balogun and Alimi, 1988). The formal credit markets have clear definition of loan default, but informal credit markets suffer from the uniqueness of such definition. In the latter market, the lender defines whether a loan is defaulted or not. Irrespective of the meaning of loan default, there are many reasons which are responsible for loan default in both formal and informal credit markets. Default on borrowed funds could arise from unfavorable circumstances that may affect the ability of the borrower to repay (Stiglitz and Weiss, 1981). The borrowers of urban informal credit markets are mostly dependent on urban informal sector of the economy which is unorganized, unregulated, and mostly legal but unregistered ((Todaro and Smith, 2017). The informal sector is characterized by a large number of small-scale production and service activities that are individually or family-owned and use simple, labor intensive technology (Todaro and Smith, 2017). The following literature identifies the factors that may cause default on loans and develops the possible hypotheses.

\subsection{Interest Rate}

Interest rate is the price for using money. It is also the amount charged for a loan. It is the cost of borrowing to a borrower which is commonly expressed as percentage of the amount borrowed. When the rate of interest on a loan is high, it increases the cost of borrowing. Consequently, the borrower's ability to repay the loan goes down because higher interest rate increases the amount of installment paid after a certain interval as set in terms and conditions of the loan. Hence, higher interest rate on a loan is usually followed by the low performance of it. There is positive relationship between interest rate and loan default.

The interest rate is identified as one of the determinants of the probability of loan default (Salas and Saurina, 2002). The high interest rate on a loan makes its regular repayment difficult by increasing the amount of installment. Again, when the interest rate is high, the minimum required rate of return from investment also becomes high 
which makes investment difficult to be profitable. Coravos (2010) finds that high interest rates increase the probability of loan default. According to Olomola (1999), delay in loan disbursement and high interest rate can significantly increase borrowing transaction cost and can also adversely affect repayment performance. This is also confirmed by Vandel (1993) who finds that high interest rates charged by banks tend to facilitate default by borrowers. Balogun and Alimi (1988) also identified high interest rate as a major cause of loan default. Mansoori (2009) shows that loan interest rate is the most important factor affecting its repayment. Among other factors like the loan size, maturity of loan and timing of loan disbursement, interest rate charged by the lender has also an impact on the repayment rates (Oke et al., 2007). Based on the previous arguments, the following empirical hypothesis is developed:

Hypothesis $1\left(H_{1}\right)$ : Interest rate does not have any relationship with loan default.

A rejection of $\mathrm{H}_{1}$ implies that there is relationship between interest rate and loan default. If the interest rate is high, it increases cost of borrowing which consequently increases the probability of loan default.

\subsection{Loan Diversion}

Loan diversion is a way to turn a loan from its proposed use to some other use. A loan can be diverted to personal cause, business use and even to pay another loan. However, if diversion is done to unproductive use, it may reduce loan repayment performance. According to Claessend, Krahnen, and Lang (2005), the probability of loan default increases when a borrower diverts the purpose for which the loan was taken. Loan diversion is one of the factors for which most of the defaults arise (Kohansal and Mansoori, 2009). Abafita (2003) confirms that loan diversion significantly increases loan default. The next hypothesis for empirical analysis is as follows:

Hypothesis $2\left(\mathrm{H}_{2}\right)$ : There is no relationship between loan diversion and loan default.

When $\mathrm{H}_{2}$ is rejected it indicates that loan diversion has some impact on loan default. When a loan is used in the promised sector which the borrower mentions while taking the loan, it has more probability to be paid in full because a loan is sanctioned when it has potential to be profitable. But when the loan is diverted to any unproductive sector, it has less chance to be paid. Hence loan default is augmented by loan diversion.

\subsection{Collateral}

Collateral can be defined as a security for a loan. The presence of collateral reduces the risk of default in that the lender can recover the loan by selling it in the market. If a borrower attaches much importance to the collateral, they will be more careful in repaying the loan so that the collateral can be taken back from the lender. As a result, the probability of default will be low. In contrast, if the recovery of the collateral is not important to the borrower, they may be careless in repaying the loan which may lead to the high probability of default. In case of small loan, a lender may consider the creditworthiness of a borrower rather than collateral to ensure the repayment of a loan. The small loans generally have less default probability than the large loans. But when the loan is large, the lender not only considers the borrower's creditworthiness, additional collateral is also taken into account. Hence the large loans are often accompanied by collateral.

Theoretical predictions differ considerably with collateral being positively related to borrower quality in some models, and negatively related in others (Bester, 1985, 1994). The theoretical prediction is that when there is asymmetric information about the borrower, the lender requires the borrower give collateral to reduce credit risk arising from such lack of information. Hence, a lower risk borrower has greater incentive to pledge collateral than a risky borrower because of his lower probability of failure and loss of collateral. As expected, a lower-risk borrower will choose the contract with collateral (Ono and Uesugi, 2009).

Just as there is information asymmetry before sanctioning a loan, it also prevails even after the loan is sanctioned in that a borrower may not use the loan in proper way, or they might use the loan for other purposes which may produce moral hazard problem. The moral hazard problem puts the lender in risky situation, so the lender will demand collateral from the borrower to recover the loan. The riskiness of the borrower will lead to collateral requirement in loan contract. Therefore, empirical evidences find both positive and negative relationships between collateral requirement and loan default. Berger and Udell (1990, 1995) find positive relationship between collateral and borrowers' ex ante risk. In contrast, Jimenez, Salas and Saurina (2006) find negative relationship between collateral and default after the loan has been granted. Low-risk borrowers generally choose contracts with a high level of collateral and high-risk borrowers, on the contrary, prefer to have loans with no collateral (Elsas and Krahnen, 2000). These opposing considerations lead to the following hypothesis:

Hypothesis $3\left(H_{3}\right)$ : Collateral does not have any relationship with loan default.

A rejection of $\mathrm{H}_{3}$ means that there is relationship between collateral and loan default. If collateral is given against a loan, the borrower generally has more incentive to repay the loan to get the collateral back. In absence of the collateral, the borrower may not be equally interested to repay the loan to take back the collateralized asset.

\subsection{Age and Education}

Age and education also affect the performance of a loan. Age is identified as possible cause of default (Balogun 
and Alimi 1988; Mokhtar, Nartea, and Gan 2012). Age may have both positive and negative effect on loan default. Oladeebo and Oladeebo (2008) reveal that age has significant positive effect on loan repayment. An empirical study by Arene (1993) reveals that there is positive contribution of age toward the creditworthiness of a borrower. Considering the data on borrower age, the subsequent hypothesis is as follows:

Hypothesis $4\left(\mathrm{H}_{4}\right)$ : There is no relationship between the borrower age and loan default.

When $\mathrm{H}_{4}$ is rejected it indicates that the borrower's age affects loan default. If the relationship is positive, the age of a borrower increases loan default, while a negative relationship shows that the borrower's age decreases loan default.

Higher levels of formal education enables borrowers to comprehend more complex information, keep records, conduct basic cash flow analysis and generally speaking, make the right investment decisions. The urban informal sector generates demand for semiskilled and unskilled labor (Todaro and Smith, 2017). The usually self-employed workers in informal sector have less formal education, are generally unskilled, and lack access to financial capital (ibid, 2017). Eze and Ibekwe (2007) find educational level to have negative effect on loan repayment default. Arene (1993) identifies that level of education contributes positively to the creditworthiness of a borrower. Abafita (2003) finds education as an important factor that enhances the loan repayment performance. Oladeebo and Oladeebo (2008) examine the determinants of loan repayment among smallholder farmers and find that level of education has significant and positive impact on loan repayment. The literature survey on education and loan default helps us to develop the following hypothesis:

Hypothesis $5\left(H_{5}\right)$ : Level of education does not have any relationship with loan default.

A rejection of $\mathrm{H}_{5}$ means that there is relationship between education and loan default. If education helps a borrower to attain more knowledge to use the loan in a better way, it certainly reduces loan default. But when education deters the borrower from getting such benefit, it definitely induces loan default.

\subsection{Income, Multiple Income Sources and Loan Size}

Income is highly linked to the repayment of a loan. Thus monthly income of a borrower is assumed to play a significant role in loan repayment. Quite expectedly, when a borrower has high monthly income from various sources including the use of current loan, the repayment capacity of the borrower will be high. On the other hand, a low monthly income of the borrower will be followed by the poor performance of the loan. Abafita (2003) showed income as a significant factor that enhances the loan repayment performance. Another study identified income to contribute positively to the creditworthiness of the borrower (Arene, 1993). In addition to regular income, the availability of different sources of income is an important indicator of loan repayment. If a borrower has multiple sources of income, their loan repayment capacity will be higher which in turn reduces loan default. Based on previous arguments regarding income and multiple sources of income, the following hypotheses can be developed:

Hypothesis $6\left(H_{6}\right)$ : There is no relationship between income and loan default.

Hypothesis $7\left(H_{7}\right)$ : Multiple sources of income do not have any relationship with loan default.

When $\mathrm{H}_{6}$ is rejected it indicates that income affects loan default. If a borrower has high income, they are more capable of repaying the loan, leading to less default on loan. On the other hand, when the income of a borrower is low, they are less capable of repaying the loan, directing towards more default on loan. A rejection of $\mathrm{H}_{7} \mathrm{means}$ that there is relationship between multiple sources of income and loan default. If a borrower has different sources of income, it increases their loan repayment performance. But in absence of various sources of income, the loan repayment performance may be hampered.

The size of loan is also a major player in informal credit markets to determine the loan default. The urban informal sector is fit for using small loans by the borrowers. The informal sector requires low amount of capital for a worker to employ (Todaro and Smith, 2017). When the loan size is small, the borrower can easily use it in different income-generating activities and repay on time. In contrast, if the loan size is big, the borrower finds few scopes in such market to use the loan. As result, the large loan in unban credit market often produces a bad result. Stiglitz (1993) noted that small size of loan is conducive to the borrowers in informal credit markets. In accordance with Abafita (2003), loan size significantly increases loan default. Oladeebo and Oladeebo (2008) showed that amount of loan is major factor that positively and significantly influences loan repayment. The following hypothesis is developed depending on the relationship between loan size and its repayment performance:

Hypothesis $8\left(H_{8}\right)$ : Loan size does not have any relationship with loan default.

The rejection of $\mathrm{H}_{8}$ means that there is relationship between loan size and loan default. A small loan has many scopes to be used in an effective way, so their repayment performance is high. But large loans have fewer scopes to be used effectively. Hence small loans have less default rate than large ones.

\section{Data, Variables and Econometric Model}

3.1 Data

For empirical analysis, the data were collected from primary source using personal interviews through 
questionnaire survey in the period of November-December 2018. The study area is Dhaka city of Bangladesh. The sample was drawn from the people who took loans from informal credit markets. A sample of four hundred respondents was selected on a nonrandom basis because of the unavailability of sampling frame. The main criterion for selection was the willingness of the respondents for us to investigate their loans, interest rates, collateral, loan diversion, monthly income, multiple sources of income, borrower age, education and loan default status. Since the informal credit markets provide financial services mainly to low income people, the respondents were selected from tea-stall owners, rickshaw pullers, hawkers, street vendors, mobile vendors, maid servants and others, considering that they represent the low income group of society.

\subsection{Variables}

A list of variables used in the empirical analysis and their definition are provided in Table $1^{1}$. The dependent variable, Default, is a dummy variable that takes a value of 1 if a borrower takes loan and defaults or 0 if the borrower takes loan and repays it successfully. The eight explanatory variables for the empirical analysis are organized to correspond to hypotheses. The first four variables are related to interest rates on loans (Intrate), loan diversion (Loandiv), collateral against loans (Collateral) and multiple sources of income (Multiinc). The next four variables are the borrower's age squared (AgeSquare), education (Education), log-transformed loan size (Logloan) and $\log$-transformed monthly income $(\log \operatorname{minc})$.

To test the first hypothesis, the cost of borrowing is proxied by the interest rate (Intrate) on loan taken by the borrower. The interest rate on a loan is shown in percentage points. There is no exact estimate of interest rates on loans in informal credit markets. However, they are calculated by dividing the difference between the amount paid and the amount borrowed by the amount borrowed. Finally, the result is expressed in annual percentage points. A negative sign is expected for this variable because it increases the cost of borrowing which then imposes extra burden on loan repayment.

The tendency of a borrower to divert the loan from the intended purpose to unproductive one is also tested to know if it is related to loan default and the loan diversion is shown by the variable Loandiv. For the purpose of this study, the diversion is explained by a dummy variable that takes a value of 1 if the loan is diverted to unproductive use or 0 if the loan is not diverted. Loan diversion which is commonly done to unproductive purposes such as consumption, repair of house, medical treatment, marriage ceremony, dowry, rituals after birth of a child and death of a person reduces the ability of the borrower to repay the loan. However, a loan may also be diverted to productive sector which results in successful repayment of the loan. As most of the diversion is done to unproductive sector which ultimately causes loan default, a negative sign, therefore, for Loandiv is expected.

To examine the relationship between collateral and loan default, the variable Collateral is considered to know whether the loan was taken with or without collateral. It is a dummy variable too and takes a value of 1 if the loan is taken with collateral or 0 if the loan is taken without collateral. Most of the loans in the informal credit markets are taken without collateral, indicating the inability of the borrower of these markets to place collateral for loans. A negative sign for Collateral is expected if the borrower is concerned about the recovery of the collateral by making the timely repayment of loan. Alternatively, if the presence of collateral induces the borrower to be less careful in repaying the loan on time, then the sign for Collateral should be negative.

If a borrower has any multiple sources of income other than the regular monthly income, it has important implication for loan repayment. The multiple sources of income are proxied by the variable Multiinc to observe its relationship with loan default. It is a dummy variable and takes a value of 1 if the borrower has multiple sources of income or 0 if the borrower does not have such sources of income. A negative sign for Multiinc is expected because the presence of many sources of income decreases the probability of loan default.

The age squared of a borrower in years (AgeSquare) is also taken as an explanatory variable. The age of a borrower has an important connotation for informal credit markets. The borrowers of such markets work mainly in informal sectors of the economy which demand huge physical labor. After a certain age, the income generation capacity of a borrower from informal sector of the economy may reduce. Age of a borrower may have both positive and negative impact on loan default. The variable Education is taken to investigate the relationship between education and loan default. A positive sign for it is expected if education is not supportive for the borrower to work in the informal job markets to generate income. On the contrary, a negative sign for it is expected if education is helpful for the borrower to work in the informal job markets to generate income.

The variable Logloan is the logarithm of loan size which is used to test its relationship with loan default. Loan size also influences loan default. If the loan size is small, it is suitable for the borrower to use in informal sector to generate income and repay the loan on time. In contrast, it is difficult for the borrower to use the large loan profitably in the informal sector. Arguably, a large loan is more likely to be defaulted in informal credit markets. Hence a positive sign for Logloan is expected. Finally, the logarithm of monthly income of a borrower is demonstrated by the variable Logminc, which is used to examine the final hypothesis. A borrower's monthly

${ }^{1}$ All tables are shown in appendices 
income has considerable effect on loan repayment too. If their monthly income is low, it reduces their ability to repay the loan on time. On the other hand, if their monthly income is high, it increases their ability to make timely repayment of the loan. Hence, it can be stated that high monthly income reduces the probability of loan default while low monthly income increases the risk of loan default. A negative sign for Logminc is expected.

\subsection{Econometric Model}

The dependent variable considered in the model is loan default at a point of time. The hypothesis posed to the data is that the likelihood of loan default is strongly related to the explanatory variables. An eight-predictor population logistic regression model to be estimated relating loan default to the predictor variables in this study took the following form:

$$
\begin{gathered}
\operatorname{In}\left[P\left(\text { Default }_{i}\right) /\left(1-P\left(\text { Default }_{i}\right)\right]=\beta_{0}+\beta_{1} \text { Intrate }_{i}+\beta_{2} \text { Laondiv }_{i}+\beta_{3} \text { Collateral }_{i}+\beta_{4} \text { Multiinc }_{i}\right. \\
+\beta_{5} \text { AgeSquare }_{i}+\beta_{6} \text { Education }_{i}+\beta_{7} \text { Logloan }_{i}+\beta_{8} \text { Logminc }_{i+} u_{i}
\end{gathered}
$$

In this model, the dependent variable is the log of the odds ratio that the outcome variable is $1 ; P($ Default $)$ is the probability of event coded with 1 and $\beta_{0}$ is the constant of the model. The parameters associated with Intrate, Loandiv, Collateral, Multiinc, AgeSquare, Education, Logloan and Logminc are $\beta_{1}, \beta_{2}, \beta_{3}, \beta_{4}, \beta_{5}, \beta_{6}, \beta_{7}$ and $\beta_{8}$ respectively. And $u_{i}$ is the error term in the model which may also be termed as other factors. The null hypothesis of the model states that all $\beta$ s are equal to zero. The rejection of this hypothesis indicates that at least one $\beta$ does not equal zero in the population, meaning the logistic regression equation can predict the probability of the outcome better than the mean of the dependent variable. The results are interpreted by using the odds ratios of the predictors. The odds ratio is obtained by using the regression coefficient of the predictor as exponent.

\section{Empirical Results}

\subsection{Descriptive Statistics}

Table 2 presents the summary of descriptive statistics of borrowers of informal credit markets. A brief description of the data to estimate the model shows that 31 percent (124 borrowers) could not repay the loans on time, but 69 percent (276 borrowers) repaid the loans on time. The predictor variables indicate that the average interest rate was 22.61 percent with the highest rate of 140 percent and the lowest of zero percent. This huge variation of interest rate is maintained by a large standard deviation of 22.61 percent. The loan diversion shows that about 23 percent of the borrowers diverted loans to unproductive purposes. Among the total borrowers, 28 percent took loan with some collateral while 72 percent obtained loan without any collateral. Only 22 percent of the borrowers had multiple sources of income. The average age of the borrowers in squared is about 1426 years. A majority of the borrowers, 54 percent, had formal education up to secondary level while 46 percent did not have any formal education. The average log-transformed loan size is 4.24 which varied from 3.3 to 5.6. The average logtransformed monthly income was 4.20 which ranged between 3.54 and 4.72 .

\subsection{Correlation Analysis}

The association between the dependent and independent variables is calculated by the help of Pearson correlation. In regression analysis, a high degree of association among independent variables that is commonly known as multicollinearity is not expected because it weakens the strength of interpretation of independent variables. A general rule to test multicollinearity is that if the correlation between two independent variables is between -0.70 and 0.70 there is likely not a problem using both of the independent variables (Lind, Marchal and Wathen, 2012). Table 3 shows there is no multicollinearity problem among the explanatory variables. The highest value of correlation is 0.34 between Logminc and Logloan which is much lower than the acceptable limit, indicating the non-existence of multicollinearity.

\subsection{Logistic Regression Analysis}

Table 4 shows the empirical results on the relationship between loan default and other factors included in the model. A comparison between those who defaulted on loans and those who did not default on the same indicates that the explanatory variables play significant roles in determining loan default. The estimated model that was fitted to the data to test the research hypotheses that the likelihood of loan default is strongly related to the explanatory variables shows the following results:

$$
\begin{aligned}
& \text { In }\left[\hat{P}\left(\text { Default }_{i}\right) /\left(1-\hat{P}\left(\text { Default }_{i}\right)\right]=-0.3249+0.0368 \text { Intrate }-1.8421 \text { Loandiv }+0.6022\right. \text { Collateral } \\
& -0.8102 \text { Multiinc }+0.0003 \text { AgeSquare }+0.4948 \text { Education }+2.0643 \text { Logloan }-2.7253 \text { Logminc }
\end{aligned}
$$

According to the model, the log of the odds of a borrower defaulted on loan is positively related to Intrate, Collateral, AgeSquare, Education and Logloan, and negatively to Loandiv, Multiinc and Logminc. Each coefficient is statistically different from zero at acceptable significance levels. There is strong evidence that one unit increase of a predictor variable will have significant impact on loan default, controlling for other variables. In other words, the higher the value of a predictor with positive coefficient, the more likely it is that a borrower will be unable to 
repay the loan on time when other variables are controlled. On the contrary, the higher the value of a predictor with negative coefficient, the less likely it is that a borrower will be unable to repay the loan on time when other variables are held constant.

The coefficient on Intrate is positive and significant, and thus provides support for the hypothesis that loan interest rate has strong relation with loan default. A borrower is more likely to default on a loan if they face an increase of interest rate on their loans. With other variables held constant, a borrower is 1.04 times more likely to default on the loan as compared with one who does not face any such interest rate increase. Quite obviously, the increase in interest rate enhances the probability of loan default by increasing the cost of borrowing and the amount of installment. This result is consistent with economic argument that the increase in interest rate raises the cost of borrowing which in turn reduces loan repayment capacity, increasing the probability of loan default.

The coefficients on Loandiv and Collateral are positive and significant, indicating that borrowers who divert loans and take loans with collateral are more likely to default on the same. The coefficient of 1.84 on Loandiv illustrates that the borrower who diverts the loan is about 6 times more likely to default in comparison with those who do not divert it, keeping other variables constant. When a loan is diverted to unproductive use it ultimately increases loan default because here the loan does not generate any income. The presence of collateral may have both positive and negative impact on loan default. The result shows that collateral is positively related to loan default and thus borrowers who take loans with collateral are more likely to default on loans. In particular, the probability of loan default increases to 1.8 for a borrower who obtains loan with collateral compared with one who takes the loan without it, holding other variables unchanged. This might be for a number of reasons. Firstly, a lender takes collateral from a borrower when the former perceives the latter risky and the risky borrowers are more prone to default. Secondly, collateral is demanded mostly from large borrowers and the repayment of large loans is more difficult than that of small ones. Thirdly, it discourages a borrower to repay the loan if the recovery of the collateral is not much important to the borrower. Finally, when a borrower places collateral against a loan, the lender has less incentive to evaluate the creditworthiness of the borrower. The lender also employs less monitoring and supervision of the loan. On the whole, all these factors result in loan default in the end.

The amount of income proves to be an important determinant of whether or not a borrower defaults on a loan. The coefficient on Logminc is negative and significant, so the null hypothesis is rejected. Therefore, monthly income of a borrower affects loan default considerably. If Logminc increases by one unit, the likelihood of loan default decreases considerably to 0.07 , keeping other variables constant. Since level of income is a key determinant of an individual's ability to repay the loan, it is perhaps not surprising to find that this variable is significant in the determination of loan default. Hence, a borrower with high monthly income is obviously less likely to default on the loan.

With regard to the multiple sources of income, borrowers with the availability of such income are less likely to default on the loan. The coefficient on Multiinc is negative and significant, providing support for the hypothesis that there is relation between multiple sources of income and loan default. If a borrower has several sources of income, the odds of being defaulted on loan decreases to 0.44 in comparison with those who do not have such sources of income. This may be explained by the fact that when a borrower has many sources of income, it helps the borrower to repay the loan in the case of unexpected shortfalls in regular income. Hence, an inverse relationship prevails between multiple sources of income and loan default.

The size of a loan appears to have impact to a great extent on loan default. The coefficient on Logloan is positive and significant which rejects the null hypothesis and states that there is strong relation between loan size and loan default. If this variable increases by one unit, the probability of loan default increases to 7.88. As mentioned elsewhere that the informal sector of an economy where a large part of informal loans are used provides many scopes for the small loans but limited opportunities for the relatively large loans. As a result, individuals with large loans are more likely to default on them.

The coefficients on the variables AgeSquare and Education are positive and significant, indicating that older and educated borrowers are more likely to default on loans. There prevails a non-linear relationship between age and loan default, meaning that the increase in age up to a certain limit reduces loan default and after that if the age increases it also induces the probability of loan default. The probability of loan default increases slightly when the age of a borrower increases by one unit, with no change in other variables. This may be because the borrowers of urban credit markets are highly involved in the economy's informal sector for generating income. The informal sector jobs like rickshaw-pulling, construction-work, hawking, street vending, working as maidservant and others demand strong physical labor. The young people are more appropriate to this sector than the older ones. With the increased of age, the income-generating capacity in the informal sector is likely to reduce and thus the default rate of older borrowers tends to increase. With regard to Education, individuals with some level of education are more likely to default on loans than the individuals with no education. The individuals with some level of education are 1.64 times likely to default on loan than those with no education. This is not surprising because informal loans are generally used in the informal sector of the economy where the educated individuals are unlikely to work. In contrast, the illiterate or less educated people can easily enter into the informal sector, generate income and make 
the timely repayment of the loan. Therefore, education is followed by more default probability in informal credit markets.

Table 5 shows the classified and true frequencies of the events and non events. The model predicts 49.19 percent defaulted loans and 90.58 percent non-defaulted loans correctly. The classification rate of non-defaulted loans as defaulted ones, also known as false positive, is 9.42 percent whereas the classification rate of defaulted loans as non-defaulted ones, also known as false negative, is 50.81 percent. Overall, the fit of the model is satisfactory with the prediction accuracy of 77.75 percent and Pseudo R-square of 26.30 percent.

\section{Concluding Remarks}

This paper investigated the determinants loan default in the urban informal credit markets of Bangladesh. A sample survey was conducted among four hundred respondents who took loans from informal credit markets. In addition to descriptive statistics, logistic regression was used to discover the factors that affect loan default. This research was motivated by the deficiency of research in the informal credit markets. The results of this study show that loan interest rates, diversion of loan, collateral, multiple sources of income, loan amount, monthly income and education are important factors that affect loan default. Among these variables, interest rate, collateral, loan amount and education increase the chances of loan default while loan diversion, multiple sources of income and monthly income decrease the likelihood of loan default. The empirical evidence supports the theoretical hypotheses in most cases. Some results contradict with theoretical propositions. However, such contradictions have their own arguments based on the character of such credit markets. The identification of the variables with their magnitude of effect towards loan default in the urban informal credit markets is the major contribution of this research.

The study has several implications for the credit suppliers of both informal and formal markets. First, by identifying the factors that affect the probability of loan defaults, it will help the informal lenders to screen potentially default borrowers more effectively and therefore improve their loan repayment record. The informal lenders could be more careful about the factors that induce loan defaults. Second, the formal financial institutions which also grant small loans similar to those of informal markets could learn valuable lessons to decrease their default rates. By understanding and analyzing the factors that affect loan defaults, the study will help the formal lenders to improve their efficiency in ways that lower default rates. Given the contribution of this research, it suffers from some limitations. The variables considered might not be appropriate proxy indicators for assessing their impact on loan default. The study is based on Dhaka city only which may be extended to other parts of the country. The study could provide better implications for the formal credit providers if borrower heterogeneity, borrowers having access to both formal and informal credit markets, could be considered. Addressing these issues is an interesting avenue for future research.

\section{Appendices}

Table 1. Description of variables

\begin{tabular}{lll}
\hline Variable & Description & Expected Sign \\
\hline Default & 1 if a borrower takes loan and defaults on it, 0 otherwise & \\
Intrate & Interest rate on a loan in percentage points & Positive $(+)$ \\
Loandiv & 1 if a loan is diverted to unproductive use, 0 otherwise & Positive $(+)$ \\
Collateral & 1 if a loan is taken with collateral, 0 otherwise & Positive/negative $(+/-)$ \\
Multiinc & 1 if a borrower has multiple sources of income, 0 otherwise & Negative $(-)$ \\
AgeSquare & Age squared of a borrower in years & Positive /negative $(+/-)$ \\
Education & 1 if a borrower has any level of education, 0 otherwise & Positive/negative $(+/-)$ \\
Logloan & Logarithm of loan amount taken by a borrower & Positive $(+)$ \\
Logminc & Logarithm of monthly income of a borrower & Negative $(-)$ \\
\hline
\end{tabular}

Table 2. Descriptive statistics

\begin{tabular}{lccccc}
\hline Variable & Obs & Mean & Std. Dev. & Min & Max \\
\hline Default & 400 & 0.31 & 0.46 & 0 & 1 \\
Intrate & 400 & 22.61 & 22.61 & 0 & 140 \\
Loandiv & 400 & 0.23 & 0.42 & 0 & 1 \\
Collateral & 400 & 0.28 & 0.45 & 0 & 1 \\
Multiinc & 400 & 0.22 & 0.41 & 0 & 1 \\
AgeSquare & 400 & 1425.99 & 792.92 & 289 & 5625 \\
Education & 400 & 0.54 & 0.5 & 0 & 1 \\
Logloan & 400 & 4.24 & 0.36 & 3.3 & 5.6 \\
Logminc & 400 & 4.2 & 0.19 & 3.54 & 4.72 \\
\hline
\end{tabular}


Table 3. Correlation matrix

\begin{tabular}{lccccccccc}
\hline & Default & Intrate & Loandiv & Collateral & Multiinc & AgeSq & Education & Logloan & Logminc \\
\hline Default & 1 & & & & & & & & \\
Intrate & 0.31 & 1.00 & & & & & & & \\
Loandiv & 0.33 & 0.05 & 1.00 & & & & & & \\
Collateral & 0.18 & 0.04 & 0.10 & 1.00 & & & & \\
Multiinc & -0.08 & -0.01 & 0.07 & 0.04 & 1.00 & & & & \\
AgeSq & 0.10 & 0.05 & 0.08 & -0.05 & 0.03 & 1.00 & & & \\
Education & -0.04 & -0.17 & -0.07 & -0.01 & 0.18 & -0.16 & 1.00 & & \\
Logloan & 0.23 & 0.12 & -0.01 & 0.22 & 0.06 & 0.04 & -0.07 & 1.00 & 1.00 \\
Logminc & -0.11 & 0.02 & -0.10 & 0.05 & 0.16 & 0.07 & 0.01 & 0.34 & \\
\hline
\end{tabular}

Table 4. Determinants of loan default - Logit Model

\begin{tabular}{llllll}
\hline Variable & Coefficients & Std. Error & Odds Ratios & Std. Error & P-value \\
\hline Constant & -0.3249 & 3.1879 & 0.7226 & 2.3035 & 0.9190 \\
Intrate & $0.0368^{* * *}$ & 0.0072 & 1.0374 & 0.0075 & 0.0000 \\
Loandiv & $1.8421^{* * *}$ & 0.3021 & 6.3099 & 1.9061 & 0.0000 \\
Collateral & $0.6022^{* *}$ & 0.281 & 1.8261 & 0.5131 & 0.0320 \\
Multiinc & $-0.8102^{* *}$ & 0.3508 & 0.4448 & 0.156 & 0.0210 \\
AgeSquare & $0.0003^{*}$ & 0.0002 & 1.0003 & 0.0002 & 0.0600 \\
Education & $0.4948^{*}$ & 0.2751 & 1.6402 & 0.4512 & 0.0720 \\
Logloan & $2.0643^{* * *}$ & 0.4381 & 7.8799 & 3.4523 & 0.0000 \\
Logminc & $-2.7253^{* * *}$ & 0.814 & 0.0655 & 0.0533 & 0.0010 \\
\hline Pseudo R & $=$ & & &
\end{tabular}

Note: $* * * * *$ and $*$ indicate statistical significance at the $1 \%, 5 \%$ and $10 \%$ levels respectively.

Table 5. Classified and true frequencies

\begin{tabular}{|c|c|c|c|}
\hline \multirow{2}{*}{ Classified } & \multicolumn{2}{|c|}{ True } & \multirow{2}{*}{ Total } \\
\hline & Default & No default & \\
\hline Default & 61 & 26 & 86 \\
\hline No default & 63 & 250 & 314 \\
\hline Total & 124 & 276 & 400 \\
\hline Sensitivity & $49.19 \%$ & False positive & $9.42 \%$ \\
\hline Specificity & $90.58 \%$ & False negative & $50.81 \%$ \\
\hline
\end{tabular}

\section{References}

Anderson T. B. and Malchow-Moller N. (2006). Strategic interaction in credit markets. Journal of Development Economics, 80, 275-298.

Bangladesh Bank. ( 2016). Annual Report 2014-2015. Dhaka: Bangladesh Bank.

Bangladesh Bureau of Statistics. (2014). Report of Rural Credit Survey 2014. Dhaka: Ministry of Planning.

Barslund, M. and Tarp, F. (2008). Formal and informal rural credit in four provinces of Vietnam. Journal of Development Studies, 44, 485-503.

Bell, C., Srinivasan, T.N. and Udry, C. (1997). Rationing, spillover, and interlinking in credit markets: The case of rural Punjab. Oxford Economic Papers, 49, 557-585.

Boucher, S. and Guirkinger, C. (2007). Risk, wealth, and sectoral choice in rural credit markets. American Journal of Agricultural Economics, 89, 991-1004.

Eswaran, M. and A. Kotwal, (1989). Implications of credit constraints for risk behavior in less developed economies. Oxford Economic Papers, 42, 473-482.

Foltz, J. D. (2004). Credit market access and profitability in Tunisian agriculture. Agricultural Economics, 30 , 229-240.

Guirkinger, C. and Boucher, S. (2007). Credit constraints and productivity in Peruvian agriculture. Working Paper No. 07-005. Department of Agricultural and Resource Economics, University of California.

He G. W. (2007). The Diversities and strategy of China rural financial institutions. The Observation of China Rural Finance, 12-20.

Hoff, K. and Stiglitz, J. E. (1990). Imperfect information and rural credit markets: Puzzles and policy perspectives. World Bank Economic Review, 4, 235-250.

Hoque, Hafiz Al Asad Bin and Khalily, M. A. Baqui, (2002). ROSCAs and ASCRAs in Bangladesh: Implications 
for financial market development. Savings and Development, 26, 395-418.

Kochar, A. (1997). An empirical investigation of rationing constraints in rural credit markets in India. Journal of Development Economics, 53, 339-371.

(1997). Does lack of access to formal credit constrain agricultural production? Evidence from the land tenancy market in rural India. American Journal of Agricultural Economics, 79, 754-763.

Lainez, Nicolas, (2014). Informal credit in Vietnam: A necessity rather than an evil. Journal of Southeast Asian Economies, 31, 147-154.

Lind, Douglas A, Marchal, William G and Wathen, Samual A. (2012). Statistical Techniques in Business and Economics, Thirteenth Edition. New Delhi: Tata McGraw Hill Education Private Limited.

Maloney, C. and Ahmed, A. B. S. (1988). Rural Savings and Credit in Bangladesh. Dhaka: The University Press Limited.

Mohieldin, M. S. and Wright, P. W. (2000). Formal and informal credit markets in Egypt. Economic Development and Cultural Change, 48, 657-670.

Stiglitz, Joseph E. (1990). Peer monitoring and credit markets. The World Bank Economic Review, 4, 351-366.

Todaro, Michael P. and Smith, Stephen C. (2017). Economic Development, Twelfth Edition. Uttar Pradesh: Pearson India Education Services Pvt. Ltd.

Zander, R., (1994). Barriers to credit access in rural Sri Lanka. In Bouman F. J. A. and Hospes, Otto (Eds.), Financial Landscapes Reconstructed: The Fine Art of Mapping Development, (12.1-12.8), Colorado: Westview Press. 